\title{
Structural Analysis of Mycolic Acids from the Cell Wall Skeleton of Rhodococcus lentifragmentus AN-115
}

\author{
By SHIGETAKA KODA, MAMORU FUJIOKA, ${ }^{*}$ MASATAKA SHIGI, \\ KEIICHI NAKASHIMA AND YUKIYOSHI MORIMOTO \\ Analytical Research Laboratories, Fujisawa Pharmaceutical Co., Kashima 2-1-6, Yodogawa-ku, \\ Osaka 532, Japan
}

(Received 26 November 1985 ; revised 14 February 1986)

The structures of the mycolic acids from the cell wall skeleton of Rhodococcus lentifragmentus AN-115 were established. Field desorption mass spectrometry of underivatized mycolic acids showed that the molecular species of the mycolic acids were distributed from $\mathrm{C}_{38}$ to $\mathrm{C}_{50}$ and the major components were $\mathrm{C}_{44}, \mathrm{C}_{46}$ and $\mathrm{C}_{48}$ mono- and dienoic $\beta$-hydroxy fatty acids. Pyrolysis gas chromatography-mass spectrometry confirmed that the mycolic acids consisted of a saturated straight $C_{12}$ and $C_{14} \alpha$-chain and an unsaturated $\beta$-chain, having mainly $C_{29}$ and $C_{31}$ carbons with one or two double bonds. The double bonds in the $\beta$-chain were established as the cis isomers by nuclear magnetic resonance. The absolute configurations of the $\alpha$ - and $\beta$ asymmetric carbons were both established as $R$ using molecular rotation data.

\section{INTRODUCTION}

The cell walls of Gram-positive bacteria of the genera Corynebacterium, Mycobacterium, Nocardia and Rhodococcus have a common construction consisting of mycolic acids, arabinogalactan and peptidoglycan (Lederer, 1971; Michel \& Bordet, 1976; Barksdale \& Kim, 1977). Mycolic acids are defined as long chain $\alpha$-branched $\beta$-hydroxy fatty acids whose structures have been extensively studied (Michel \& Bordet, 1976; Minnikin \& Goodfellow, 1980; Tomiyasu \& Yano, 1984). Mycolic acids from Nocardia have a range from $C_{36}$ to $C_{66}$ usually with a saturated straight chain at the $\alpha$-position $(\alpha$-chain) and an unsaturated straight chain at the $\beta$-position ( $\beta$-chain) containing from one to three double bonds. Similar mycolic acids have been characterized from members of the genus Rhodococcus (Minnikin \& Goodfellow, 1980).

The present report deals with the structures of the mycolic acids from the cell wall skeleton of Rhodococcus lentifragmentus AN-115, including determinations of the molecular species distribution, carbon numbers of $\alpha$ - and $\beta$-chains, geometrical isomerism of the double bonds and the absolute configuration.

\section{METHODS}

Organism. The cell wall skeleton was prepared, according to Fujioka et al. (1985), from 'Nocardia rubra' AN-I15 preserved in the Research Laboratories of Fujisawa Pharmaceutical Co. (Osaka, Japan). Organisms labelled ' $N$. rubra' should now properly be considered as members of the species Rhodococcus lentifragmentus (Tsukamura, 1985).

Mycolic acids. About $200 \mathrm{mg}$ of the cell walls of $R$. lentifragmentus was hydrolysed with $10 \mathrm{ml} 5 \%(\mathrm{w} / \mathrm{v}) \mathrm{KOH}$ in methanol at $100^{\circ} \mathrm{C}$ for $3 \mathrm{~h}$ in a sealed tube. After acidification with $10 \mathrm{ml} \mathrm{l} \mathrm{M-HCl}$, the sample was extracted three times with $25 \mathrm{ml}$ diethyl ether. The combined ethereal solution was rinsed twice with water and then evaporated to dryness. The mycolic acids $\left(R_{F} 0.49\right)$ were purified by thin-layer chromatography (TLC) using Merck silica gel 60 plates and chloroform/methanol $(9: 1, \mathrm{v} / \mathrm{v})$.

Methyl mycolates. The mycolic acids were esterified in $\mathrm{HCl}$ saturated methanol under reflux for $1 \mathrm{~h}$. The sample was evaporated to dryness and the methyl mycolates $\left(R_{F} 0 \cdot 3\right)$ were purified by TLC using hexane/diethyl ether 


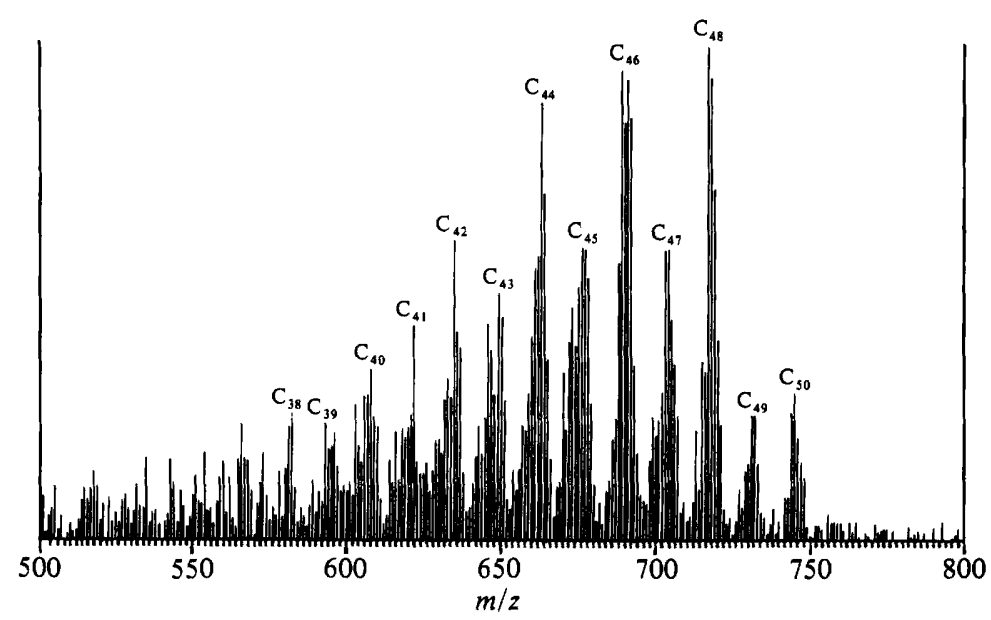

Fig. 1. Field desorption mass spectrum of the mycolic acids from the cell wall skeleton of $R$. lentifragmentus AN-115.

$(2: 1, \mathrm{v} / \mathrm{v})$. The diastereoisomeric methyl mycolates were prepared by the alkaline isomerization method of Etémadi (1967a).

Preparation of trimethylsilyl derivatives of the methyl mycolates. The mycolic acids in $2 \mathrm{ml}$ chloroform were esterified with $0.4 \mathrm{ml} \mathrm{N}, N$-dimethylformamide dimethyl acetal for $10 \mathrm{~min}$ at room temperature and then silylated with $0.4 \mathrm{ml}$ acetonitrile/bis(trimethylsilyl)acetamide/trimethylchlorosilane $(75: 25: 4$, by vol.) for $10 \mathrm{~min}$ at room temperature.

Analytical methods. Field desorption mass spectra were taken with a Jeol JMS-D300 mass spectrometer equipped with a Jeol JMA-2000 mass data analysis system. The sample was applied to a Jeol silicon emitter, the heating current being controlled from 15 to $20 \mathrm{~mA}$. Proton magnetic resonance spectra were recorded in $\mathrm{CDCl}_{3}$ using tetramethylsilane as an internal standard on Jeol JNM-PMX 60 and Jeol PFT-100 instruments. Methyl mycolates were pyrolysed at $280^{\circ} \mathrm{C}$ for $10 \mathrm{~min}$ in vacuo. The product was dissolved in chloroform and applied to a Hitachi M-80 mass spectrometer fitted with $1.5 \%$ OV-17 on a Chromosorb W HP column $(2 \mathrm{~mm} \times 50 \mathrm{~cm})$. The conditions of gas chromatography-mass spectrometry (GC-MS) were as follows: column temperature, 160$290{ }^{\circ} \mathrm{C}$; injection temperature, $295^{\circ} \mathrm{C}$; ionizing energy, $20 \mathrm{eV}$; total emission current, $100 \mu \mathrm{A}$. Gas chromatograms of the trimethylsilylated methyl mycolates were taken on a Shimadzu GC-7A gas chromatograph fitted with a Diasolid ZS column $(3 \mathrm{~mm} \times 100 \mathrm{~cm})$ under the following conditions: column temperature, 240 $340^{\circ} \mathrm{C}$; injection temperature, $350^{\circ} \mathrm{C}$; flame ionization detector temperature, $350{ }^{\circ} \mathrm{C}$. Molecular rotations were measured in chloroform at $20^{\circ} \mathrm{C}$ with a Jasco $\mathrm{J}-20$ spectropolarimeter.

\section{RESULTS AND DISCUSSION}

Field desorption MS has been used for characterization and determination of the $M_{\mathrm{r}}$ distribution of synthetic polymers, since it provides predominantly molecular ions or quasimolecular ions without, or with very few weak, fragment ions (Schulten, 1981). The field desorption mass spectrum of the mycolic acids of the $R$. lentifragmentus cell wall is shown in Fig. 1. It is interesting to note that the distribution of mass spectral peaks essentially corresponds to the peaks in the gas chromatogram of the trimethylsilylated methyl mycolates (Fig. 2).

The composition of each molecular species, determined by MS, and their molecular formulae are summarized in Table 1, which shows that the molecular species of the mycolic acids ranged from $\mathrm{C}_{38}$ to $\mathrm{C}_{50}$ and the major components were $\mathrm{C}_{44}, \mathrm{C}_{46}$ and $\mathrm{C}_{48}$ with one or two double bonds. Most of the minor components also contained one or two double bonds with the exception of some of the short chain components such as $\mathrm{C}_{38: 0}, \mathrm{C}_{40: 0}$ and $\mathrm{C}_{41: 0}$. Very small amounts of $\mathrm{C}_{45: 3}$ and $\mathrm{C}_{48: 3}$ were also observed, so that trienoic components were also present in the mycolic acids. In agreement with Tomiyasu \& Yano (1984), it was also apparent that the longer chain components contained greater numbers of double bonds. The present results indicate that field desorption MS is a useful method for determining detailed molecular species distribution as well as $M_{\mathrm{r}}$ values of mycolic acids without derivatizations. It may also be useful for larger, more involatile mycolic acids where GC or GC-MS operations may be difficult. 


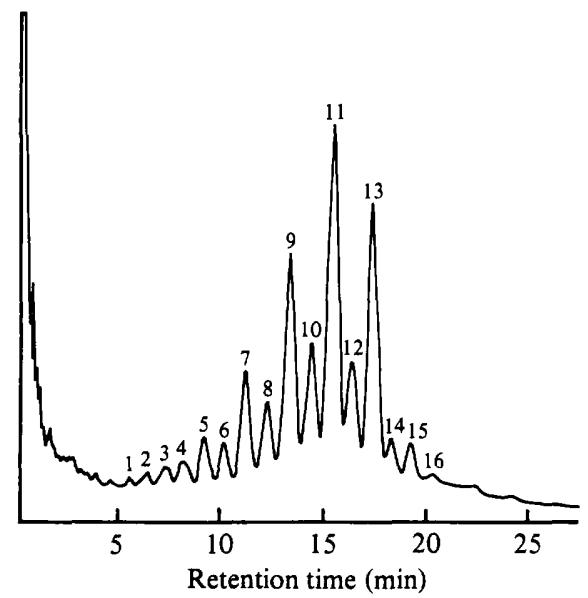

Fig. 2. Gas chromatogram of the trimethylsilyl derivatives of the methyl mycolates from the cell wall skeleton of $R$. lentifragmentus AN-115.

Table 1. Field desorption mass spectrometric analysis of the mycolic acids from the cell wall skeleton of R. lentifragmentus $A N-115$

\begin{tabular}{|c|c|c|c|}
\hline$M_{\mathrm{r}}^{*}$ & Formula & $\begin{array}{l}\text { Carbon and } \\
\text { double bond no. }\end{array}$ & Peak no. $†$ \\
\hline 580 & $\mathrm{C}_{38} \mathrm{H}_{76} \mathrm{O}_{3}$ & $C_{38: 0}$ & 3 \\
\hline $\begin{array}{l}592 \\
594\end{array}$ & $\begin{array}{l}\mathrm{C}_{39} \mathrm{H}_{76} \mathrm{O}_{3} \\
\mathrm{C}_{39} \mathrm{H}_{78} \mathrm{O}_{3}\end{array}$ & $\begin{array}{l}C_{39: 0} \\
C_{39: 1}\end{array}$ & $\begin{array}{l}4 \\
4\end{array}$ \\
\hline $\begin{array}{l}606 \\
608\end{array}$ & $\begin{array}{l}\mathrm{C}_{40} \mathrm{H}_{78} \mathrm{O}_{3} \\
\mathrm{C}_{40} \mathrm{H}_{80} \mathrm{O}_{3}\end{array}$ & $\begin{array}{l}C_{40: 1} \\
C_{40: 0}\end{array}$ & $\begin{array}{l}5 \\
5\end{array}$ \\
\hline 622 & $\mathrm{C}_{41} \mathrm{H}_{82} \mathrm{O}_{3}$ & $C_{41: 0}$ & 6 \\
\hline $\begin{array}{l}632 \\
634 \\
636\end{array}$ & $\begin{array}{l}\mathrm{C}_{42} \mathrm{H}_{80} \mathrm{O}_{3} \\
\mathrm{C}_{42} \mathrm{H}_{82} \mathrm{O}_{3} \\
\mathrm{C}_{42} \mathrm{H}_{84} \mathrm{O}_{3}\end{array}$ & $\begin{array}{l}C_{42: 2} \\
C_{42: 1} \\
C_{42: 0}\end{array}$ & $\begin{array}{l}7 \\
7 \\
7\end{array}$ \\
\hline $\begin{array}{l}646 \\
648 \\
650\end{array}$ & $\begin{array}{l}\mathrm{C}_{43} \mathrm{H}_{82} \mathrm{O}_{3} \\
\mathrm{C}_{43} \mathrm{H}_{84} \mathrm{O}_{3} \\
\mathrm{C}_{43} \mathrm{H}_{86} \mathrm{O}_{3}\end{array}$ & $\begin{array}{l}C_{43: 2} \\
C_{43: 1} \\
C_{43: 0}\end{array}$ & $\begin{array}{l}8 \\
8 \\
8\end{array}$ \\
\hline $\begin{array}{l}660 \\
662 \\
664\end{array}$ & $\begin{array}{l}\mathrm{C}_{44} \mathrm{H}_{84} \mathrm{O}_{3} \\
\mathrm{C}_{44} \mathrm{H}_{86} \mathrm{O}_{3} \\
\mathrm{C}_{44} \mathrm{H}_{88} \mathrm{O}_{3}\end{array}$ & $\begin{array}{l}C_{44: 2} \\
C_{44: 1} \\
C_{44: 0}\end{array}$ & $\begin{array}{l}9 \\
9 \\
9\end{array}$ \\
\hline $\begin{array}{l}672 \\
674 \\
676 \\
678\end{array}$ & $\begin{array}{l}\mathrm{C}_{45} \mathrm{H}_{84} \mathrm{O}_{3} \\
\mathrm{C}_{45} \mathrm{H}_{86} \mathrm{O}_{3} \\
\mathrm{C}_{45} \mathrm{H}_{88} \mathrm{O}_{3} \\
\mathrm{C}_{45} \mathrm{H}_{90} \mathrm{O}_{3}\end{array}$ & $\begin{array}{l}C_{45: 3} \\
C_{45: 2} \\
C_{45: 1} \\
C_{45: 0}\end{array}$ & $\begin{array}{l}10 \\
10 \\
10 \\
10\end{array}$ \\
\hline $\begin{array}{l}688 \\
690 \\
692\end{array}$ & $\begin{array}{l}\mathrm{C}_{46} \mathrm{H}_{88} \mathrm{O}_{3} \\
\mathrm{C}_{46} \mathrm{H}_{90} \mathrm{O}_{3} \\
\mathrm{C}_{46} \mathrm{H}_{92} \mathrm{O}_{3}\end{array}$ & $\begin{array}{l}C_{46: 2} \\
C_{46: 1} \\
C_{46: 0}\end{array}$ & $\begin{array}{l}11 \\
11 \\
11\end{array}$ \\
\hline $\begin{array}{l}702 \\
704\end{array}$ & $\begin{array}{l}\mathrm{C}_{4}, \mathrm{H}_{90} \mathrm{O}_{3} \\
\mathrm{C}_{47} \mathrm{H}_{92} \mathrm{O}_{3}\end{array}$ & $\begin{array}{l}C_{47: 2} \\
C_{47: 1}\end{array}$ & $\begin{array}{l}12 \\
12\end{array}$ \\
\hline $\begin{array}{l}714 \\
716 \\
718\end{array}$ & $\begin{array}{l}\mathrm{C}_{48} \mathrm{H}_{90} \mathrm{O}_{3} \\
\mathrm{C}_{48} \mathrm{H}_{92} \mathrm{O}_{3} \\
\mathrm{C}_{48} \mathrm{H}_{94} \mathrm{O}_{3}\end{array}$ & $\begin{array}{l}C_{48: 3} \\
C_{48: 2} \\
C_{48: 1}\end{array}$ & $\begin{array}{l}13 \\
13 \\
13\end{array}$ \\
\hline $\begin{array}{l}730 \\
732\end{array}$ & $\begin{array}{l}\mathrm{C}_{49} \mathrm{H}_{94} \mathrm{O}_{3} \\
\mathrm{C}_{49} \mathrm{H}_{96} \mathrm{O}_{3}\end{array}$ & $\begin{array}{l}C_{49: 2} \\
C_{49: 1}\end{array}$ & $\begin{array}{l}14 \\
14\end{array}$ \\
\hline $\begin{array}{l}744 \\
746\end{array}$ & $\begin{array}{l}\mathrm{C}_{50} \mathrm{H}_{96} \mathrm{O}_{3} \\
\mathrm{C}_{50} \mathrm{H}_{98} \mathrm{O}_{3}\end{array}$ & $\begin{array}{l}\mathrm{C}_{50: 2} \\
\mathrm{C}_{50: 1}\end{array}$ & $\begin{array}{l}15 \\
15\end{array}$ \\
\hline
\end{tabular}




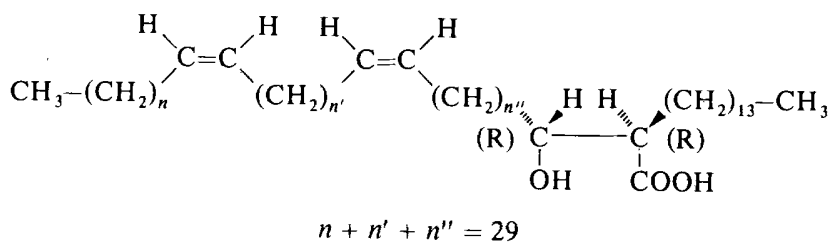

Fig. 3. Structure of the $\mathrm{C}_{46: 2}$ mycolic acid from the cell wall skeleton of $R$. lentifragmentus AN-115.

Methyl mycolates can be easily pyrolysed into methyl esters of fatty acids and meroaldehydes (Etémadi, 1967b). Pyrolysis followed by GC-MS of the methyl mycolates showed that the $\alpha$ chain was saturated $\mathrm{C}_{10}, \mathrm{C}_{11}, C_{12}, \mathrm{C}_{13}, C_{14}, \mathrm{C}_{15}$ and $\mathrm{C}_{16}$, and the $\beta$-chain was unsaturated $\mathrm{C}_{23}$, $\mathrm{C}_{24}, \mathrm{C}_{25}, \mathrm{C}_{26}, \mathrm{C}_{27}, \mathrm{C}_{28}, C_{29}, \mathrm{C}_{30}, C_{31}, \mathrm{C}_{32}$ and $\mathrm{C}_{33}$ mainly with one or two double bonds, the major components being shown in italic type.

The chemical shifts in the proton magnetic resonance spectrum $(100 \mathrm{MHz})$ of the mycolic acids are as follows: methyl protons, 0.89 p.p.m. (triplet); methylene protons, 1.25 p.p.m. (singlet); methylene protons vicinal to olefin groups, 2.01 p.p.m. (broad singlet); $\alpha$-methine protons, 2.34 p.p.m. (broad singlet); $\beta$-methine protons, 3.66 p.p.m. (broad singlet); olefinic protons, 5.32 p.p.m. (multiplet). Analysis of the olefinic signal pattern at about 5.3 p.p.m. on proton magnetic resonance spectra can provide information to distinguish between cis and trans configurations of non-conjugated alkenoic acids (Purcell et al., 1966; Frost \& Gunstone, 1975). Oleic and elaidic acids were chosen as suitable materials for comparing the splitting patterns of the mycolic acid olefinic protons. The splitting pattern of the signal for the mycolic acids was very similar to that of oleic acid but not to that of elaidic acid, showing that the mycolic acids had exclusively cis configuration.

Four optical isomers are theoretically possible for mycolic acids because they have two asymmetric carbon atoms at the $\alpha$ - and $\beta$-positions. A method for determining the absolute configuration of mycolic acids has been developed (Asselineau \& Asselineau, 1966; Tocanne \& Asselineau, 1968). The molecular rotation values of methyl mycolates, having $\mathrm{R}$ configurations at both $\alpha$ - and $\beta$-asymmetric carbon atoms, were about $+40^{\circ}$ and those of diastereoisomers, having the opposite configuration at the $\alpha$-carbon, were about $-10^{\circ}$ in several kinds of mycolic acids (Asselineau et al., 1970), including mycolic acids having double bonds only in the $\beta$-chain. Our molecular rotation data of the methyl mycolates from $R$. lentifragmentus and their diastereoisomers about the $\alpha$-carbon, obtained by the method of Etémadi (1967a), were $+39^{\circ}$ and $-7^{\circ}$ respectively. These values show that both asymmetric carbon atoms of these mycolic acids adopt the $\mathrm{R}$ configuration.

Previous GC-MS studies of trimethylsilylated methyl mycolates have demonstrated the precise distribution of $M_{\mathrm{r}}$, double bond numbers and $\alpha$ - and $\beta$-chain structures of the mycolic acids from $R$. lentifragmentus (' $N$. rubra') (Yano et al., 1978; Tomiyasu et al., 1981; Tomiyasu \& Yano, 1984). Our field desorption MS of the underivatized mycolic acids and pyrolysis followed by GC-MS of the methyl mycolates provides the same result, namely that the mycolic acids from $R$. lentifragmentus $\mathrm{AN}-115$ ranged from $\mathrm{C}_{38}$ to $\mathrm{C}_{50}, \mathrm{C}_{44}, \mathrm{C}_{46}$ and $\mathrm{C}_{48}$ being the major components, and their double bonds of 0 to 3 were located in the $\beta$-chains, which were mainly $\mathrm{C}_{29}$ and $\mathrm{C}_{31}$. A tendency for the longer chain components to contain greater numbers of double bonds was also observed.

The chemical structure of a mycolic acid with carbon number 46 and two double bonds is illustrated in Fig. 3 as a representative mycolic acid from the cell wall skeleton of $R$. lentifragmentus AN-115.

\section{REFERENCES}

Asselineau, C. \& Asselineau, J. (1966). Stéréochemie de l'acide corynomycolique. Bulletin de la Société chimique de France, 1992-1999.
Asselineau, C., Tocanne, G. \& Tocanne, J.-F. (1970). Stéréochemie des acides mycoliques. Bulletin de la Société chimique de France, 1456-1459. 
BARKSDALE, L. \& KIM, K.-S. (1977). Mycobacterium. Bacteriological Reviews 41, 217-372.

ETÉMADI, A. H. (1967a). Isomerisation de mycolates de methyle en milieu alcalin. Chemistry and Physics of Lipids 1, 165-175.

EtÉmadi, A. H. $(1967 b)$. The use of pyrolysis gas chromatography and mass spectroscopy in the study of the structure of mycolic acids. Journal of Gas Chromatography 5, 447-456.

Frost, D. J. \& Gunstone, F. D. (1975). The PMR analysis of non-conjugated alkenoic and alkynoic acids and esters. Chemistry and Physics of Lipids 15, 53-85.

Fujioka, M., Koda, S. \& Morimoto, Y. (1985). Novel glycosidic linkage between arabinogalactan and peptidoglycan in the cell wall skeleton of Nocardia rubra AN-115. Journal of General Microbiology 131, 1323-1329.

Lederer, E. (1971). The mycobacterial cell wall. Pure and Applied Chemistry 25, 135-165.

Michel, G. \& BoRDET, C. (1976). Cell walls of Nocardiae. In The Biology of Nocardiae, pp. 141-159. Edited by M. Goodfellow, G. H. Brownell \& J. A. Serrano. London: Academic Press.

Minnikin, D. E. \& Goodfellow, M. (1980). Lipid composition in the classification and identification of acid-fast bacteria. In Microbiological Classification and Identification, pp. 189-256. Edited by $\mathrm{M}$. Goodfellow \& R. G. Board. London: Academic Press.

Purcell, J. M., Morris, S. G. \& Susi, H. (1966). Proton magnetic resonance spectra of unsaturated fatty acids. Analytical Chemistry 38, 588-592.
SCHUlteN, H.-R. (1981). Advances in field desorption mass spectrometry. In Soft Ionization Biological Mass Spectrometry, pp. 6-38. Edited by H. R. Morris. London: Heyden \& Son.

Tocanne, J.-F. \& Asselineau, C. (1968). Étude stéréochimique des acides aliphatiques $\alpha$-ramifies $\beta$ hydroxylés. Configuration absolue de l'acide corynomycolique. Bulletin de la Société chimique de France, 4519-4525.

TOMIYASU, I. \& YANO, I. (1984). Isonicotinic acid hydrazide induced changes and inhibition in mycolic acid synthesis in Nocardia and related taxa. Archives of Microbiology 137, 316-323.

Tomiyasu, I., Toriyama, S., Yano, I. \& Masui, M. (1981). Changes in molecular species composition of nocardomycolic acid in Nocardia rubra by the growth temperature. Chemistry and Physics of Lipids 28, 4154.

Tsukamura, M. (1985). Priority of Rhodococcus lentifragmentus (Kruse 1896; Tsukamura et al. 1975) Tsukamura 1978 comb. nov. over Rhodococcus ruber (Kruse 1896) Goodfellow and Alderson 1980. International Journal of Systematic Bacteriology 35, 124125.

Yano, I., Kageyama, K., Ohno, Y., Masul, M., Kusunose, E., Kusunose, M. \& Akimori, N. (1978). Separation and analysis of molecular species of mycolic acids in Nocardia and related taxa by gas chromatography mass spectrometry. Biomedical Mass Spectrometry 5, 14-24. 